\title{
Does corporate internationalization contribute to companies' operational efficiency? Evidence form Russian companies
}

\author{
Shcherbakov Dmitry Y. ${ }^{16}$
}

Corporate international diversification has become a widely used growth strategy. However, the majority of scientific researches insist on its value-destroying pattern. As most of these researches are focused on companies from the developed countries the experience of companies from developing countries remains fairly unexplored.

The current paper proposes an estimation of internalization-performance relationship from operational efficiency prospect. The proposed model has been empirically tested on a sample of large Russian companies. The results identify a non-linear $U$-shape relationship between a degree of internationalization and companies' return on capital employed. Overall for the majority of companies international diversification refers to diminish in operational efficiency.

\section{JEL: F23, F30, G30, G34}

Keywords: corporate international diversification, internationalization, corporate performance, multinational corporations, return on capital employed

\section{Introduction}

During the last two decades the level of corporate international diversification (CID) has been significantly growing both in developed and developing countries. As an example in mid 2000-s a number of cross-border M\&A deals grew by $40 \%$ per annum in manufacturing industries of some of European countries (Coeurdacier et al., 2009). In years 2000 - 2007 an average growth rate of outbound foreign direct investments of Russian companies was about $40 \%$ per annum (Plotnikov, 2010).

According to the majority of researches on performance of cross-border diversification the companies get into the internationalization paradox - the scholars demonstrate that the internationalization activities are mainly value-destroying. As most of these researches are focused on companies from developed countries the internationalization efficiency of companies from developing countries remain fairly unexplored.

This paper contributes to the existing literature by proposing a model for estimation of internationalization - operational performance relationship which is applied for a sample of large Russian companies. As for current operating performance indicator the return on capital employed is used.

The paper is structured as follows: in the first section the theoretical background is summarized on the basis of existing researches and the hypotheses are formulated. The data and the methods are explained in section two. In section three we discuss the empirical results. Finally, the overall conclusions and policy implications are presented.

\section{Theoretical background and hypotheses Research approach}

In the current research uses accounting studies methodology for analysis of internationalization-performance relationship. The methodology is based on identification of relationship between accounting-based measures of corporate performance and a degree of

\footnotetext{
${ }^{16}$ Магистр экономики Университета Сорбонна Париж-1 (2009), выпускник аспирантуры факультета экономики НИУ-ВШЭ, менеджер отдела стратегии и операционной эффективности департамента бизнесконсультирования PricewaterhouseCoopers Russia B.V.
} 
internationalization of business (DOI) with use if regression analysis.

The existing researches differ a lot by the use of both operating performance indicators and measures of degree of internationalization:

- depending on the choice of measure of DOI it is possible to control different internationalization patterns. Usually international diversification is classified into two classes - diversification of assets and diversification of markets. The most commonly used measures of these types of CID are foreign-assets-to-total-assets (FATA) and foreign-salesto-total-sales (FSTS) ratios correspondently.

- a use of different corporate performance indicators also allows to study different types of effects of internationalization. Typically as indicators of current operating performance the following measures are used: revenue, operating cash flow, EBIT-based measures (EBIT margin, ROS, ROE, ROA, etc.), others (see Qian and Li (2002), Guler et al. (2003), Moeller and Schlingemann (2004), Lu and Beamish (2004), Contractor et al. (2007), Bobillo et al. (2010), Rugman and Chang (2010)).

A thorough review of research literature one may find in the studies of Bruener R. (2004) or Hitt et al. (2006).

\section{Hypotheses}

This section contains the hypotheses which will be tested on a sample of Russian companies.

The majority of internationalization-performance researches state for a non-linear pattern of relationship between DOI and operational efficiency measures. Lu and Beamish (2004) identified the most general pattern of this relationship demonstrated by horizontal S-shape curve which was also supported by Bobillo et al. (2010), Rugman and Chang (2010) mainly for developed countries. The S-shape curve consists of 3 sequential intervals:

1) at a low level of international diversification the operating performance is decreasing with an increase in DOI since internationalization-related costs (learning costs, cost of coordination and control of abroad divisions, other transaction costs) are too high in comparison with a low marginal increase in efficiency and growth of abroad sales;

2) at a medium level of internationalization the performance is supposed to increase due to significant benefits (economy of scale and scope, diversification of country risks, access to foreign knowledge and cheaper resources, increase of market power, etc.) which are higher than transaction costs;

3) at a high level of DOI the performance may start descending again due to the unmanageable international complexity of organizations (over-internationalization stage).

For the emerging markets (India) a U-shaped relationship has been identified by Contractor et al. (2007). It was argued that the companies from the emerging markets typically do not reach such degree of complexity related to an over-internationalization stage when further internationalization becomes value destroying.

Hypothesis 1.1: The relationship between ROCE and DOI is non-linear and follows an Ushape pattern for Russian companies

Hitt et al. (1997) have shown that the internationalization-performance relationship significantly depends on the product diversification of a company. Typically the internationalization effect is more positive when the company is characterized by a higher level of related product diversification (Chang, Wang, 2007). It is described by the organizational design of product diversified companies which is usually better adapted to international diversification.

Hypothesis 1.2: The level of product diversification has a positive impact on operational efficiency of Russian companies related to internationalization

Lu and Beamish (2004) have identified a positive impact of investments in intangible assets (may be proxied by $\mathrm{R} \& \mathrm{D}$ and advertising intensity) over internationalization performance. The authors explain this finding by the following reasons: 1) once being acquired intangible assets do not depreciate more intensively when they are applied in different markets in comparison to domestic market only, thus allowing an internationalized firm to generate higher returns on 
intangible assets comparing to its non-internationalized pier; 2) a cross-border diversified company has an ability to mitigate country-specific risks related to the intellectual property.

Hypothesis 1.3: The value of intangible assets has a positive impact on ROCE-DOI relationship for Russian companies

\section{The methods \\ The sample}

The proposed research framework is applied on a sample of Russian companies. We have collected the data of 50 Russian companies which included:

- 40 internationalized companies which earns revenue from abroad markets and have made at least one cross-border acquisition in the period from 2000 to 2010 ;

- 10 domestic companies with a zero internationalization level which are included in the list of 200 Russian companies with the highest capitalization.

All chosen companies are public and disclose all the key information which should be used in the current research. The data is derived from Bloomberg database. The data has been collected for a time span from year 2005 to year 2010. Overall we have an unbalanced panel of 183 observations. Descriptive statistics for the dataset is depicted in Table 1. The sample includes companies from 6 industries: mining (16\% of companies in the sample), construction $(2 \%)$, manufacturing (54\%), transportation and utilities $(8 \%)$, retail trade $(9 \%)$ and services $(10 \%)$. The industry classification follows the SIC standard.

Table 1

Variable's description and statistics for the sample

\begin{tabular}{|c|c|c|c|c|c|c|}
\hline Variable & Description & Obs & Mean & S. D. & Min & Max \\
\hline \multicolumn{7}{|l|}{$\overline{\text { Efficiency measures }}$} \\
\hline ROCE & Return on capital employed (\%) & 178 & 24,16 & 18,53 & $-19,58$ & 108,44 \\
\hline \multicolumn{7}{|c|}{ Internationalization measures (DOI) } \\
\hline fsts & Foreign sales to total sales & 183 & 0,32 & 0,32 & 0,00 & 0,98 \\
\hline fata & Foreign assets to total assets & 103 & 0,10 & 0,19 & 0,00 & 1,00 \\
\hline \multicolumn{7}{|c|}{ Basic performance determinants } \\
\hline ln_sales & Company size (log of sales) & 183 & 7,64 & 2,02 & 2,19 & 11,52 \\
\hline asset_turnover & Asset turnover & 180 & 0,92 & 0,61 & 0,01 & 5,03 \\
\hline prod_divn_hhi & $\begin{array}{l}\text { Product diversification (Her- } \\
\text { findahl-Hirschman Index) }\end{array}$ & 181 & 0,72 & 0,26 & 0,26 & 1,00 \\
\hline intang_to_tot_assets & Intangible assets / total assets & 171 & 0,17 & 0,19 & 0,00 & 2,55 \\
\hline diverse & FSTS / prod_divn_hhi & 181 & 0,56 & 0,67 & 0,00 & 3,68 \\
\hline $\begin{array}{l}\text { intasssales_to_fsts } \\
\text { Industry dummies (SIC) }\end{array}$ & FSTS * intang_asset_to_sales & 172 & 0,13 & 0,25 & 0,00 & 1,45 \\
\hline SIC2 & Mining industry dummy & 183 & 0,16 & 0,37 & 0,00 & 1,00 \\
\hline SIC3 & Construction industry dummy & 183 & 0,02 & 0,15 & 0,00 & 1,00 \\
\hline SIC4 & Manufacturing industry dummy & 183 & 0,54 & 0,50 & 0,00 & 1,00 \\
\hline SIC5 & $\begin{array}{l}\text { Transportation and public } \\
\text { utilities dummy }\end{array}$ & 183 & 0,08 & 0,28 & 0,00 & 1,00 \\
\hline SIC7 & Retail trade sector dummy & 183 & 0,09 & 0,28 & 0,00 & 1,00 \\
\hline SIC9 & Services sector dummy & 183 & 0,10 & 0,31 & 0,00 & 1,00 \\
\hline
\end{tabular}

\section{Modeling procedures}

We do estimations an equation for ROCE - internationalization relationship on panel data for years 2005-2010. For panel-data regressions we employ GLS estimates under assumption of random effects. A Hausman test is used in order to test an endogeneity problem. We test for nonlinearity and other formulated hypotheses.

As for DOI the FSTS measure is used. We do not employ into the regressions the FATA measure because of its low availability (it is accessible only for less than a half of the companies in 
the sample). Nevertheless, due to a sample selection procedure where we have chosen the companies which conducted at least one cross-border M\&A in the last decade, both assets and market international diversification are analyzed. As it is expected the correlation between FATA and FSTS is rather high (a correlation coefficient between FSTS and FATA equals 0.63 on average during 2005-2010 period; it was constantly growing and reached 0.79 for year 2010). Thus in this study even using FSTS measure we indeed control both international diversification of markets and assets.

An equation for ROCE has the following form:

$$
R O C E=X * \delta+\alpha 1 * f s t s+\alpha 2 * f s t s^{2}+\alpha 3 * f s t s^{3}+\varphi
$$

where $\mathrm{X}$ is a matrix of the following control variables: firm size (measured by logarithm of sales, In_sales), product diversification (measured by Herfindahl-Hirschman Index calculated on the basis of product segmentation disclosed by firms in their financial statements, prod_divn_hhi), book value of intangible assets normalized by total amount of assets (intang_to_tot_assets), managerial agency costs (inverse of assets turnover ratio, asset_turnover) and composite variables of DOI and product diversification as well as DOI and intangible assets ratio (diverse and intasssales_to_fsts correspondently, which are required for testing the hypotheses 1.2 and 1.3), industry and crisis years dummies.

\section{Findings \\ Testing the ROCE to DOI relationship}

In order to define a proper functional form of the ROCE-DOI relationship all the described variables have been initially included in the equation (1):

- To measure a direct internationalization impact on performance the cubic polynomial function components has been employed ( $f s t s, f s t s^{2}, f s t s^{3}$ ). It allows to test the formulated hypothesis of non-linearity of internationalization impact;

- To test two other hypotheses of an influence of product diversification and intangible assets on ROCE-DOI relationship "diverse" and "intasssales_to_fsts" were used (see Table 1). follows:

The results of estimation are represented in Table 2 and Figure 1 . Our main findings are as

- We found out that the ROCE-DOI relationship follows a U-shape pattern (see Figure 1). At the early stage of internationalization (when the share of foreign sales is in the interval between $0 \%$ and approximately $50 \%$ ) cross-border diversification significantly diminishes the return on capital employed. At the later stages of internationalization (when the share of foreign sales exceeds half of total sales) a sharp increase in profitability has been identified. As it is shown the initial drop in efficiency is compensated by its subsequent growth only at the level of absolute internationalization (FSTS $>90 \%$ ). The significant drop in ROCE at the early stage of internationalization of Russian companies may be explained by both strategic motives (which presume return in the long run, e.g. a motive of acquisition of innovative technologies or new knowledge) and at the same time by possible irrationality of managerial behavior (such phenomenon as managerialism and hubris are studied in Seth et al. (2000)).

- Although in our sample MNCs are characterized by a higher degree of product diversification and endowment of intangible assets, we did not find any significant influence of these factors on ROCE (the corresponding variables "prod_divn_hhi", "diverse", “intang_asset_to_sales", "intasssales_to_fsts" are absolutely insignificant). 
Results of estimation of ROCE-DOI equation

\begin{tabular}{ll}
\hline Variable & Model 1.3 (2005-2010) $\dagger$ \\
\hline fsts & $-35,8^{* *}(-1,95)$ \\
fsts_2 & $38,96^{* *}(1,78)$ \\
fsts_3 & - \\
ln_sales & $2,25^{* * *}(2,36)$ \\
prod_divn_hhi & $-7,28(-1,16)$ \\
asset_turnover & $7,26^{* * *}(2,37)$ \\
SIC4 & $10,42^{* * *}(2,78)$ \\
SIC9 & $18,53^{* * *}(3,06)$ \\
d2008 & $-3,99(-1,42)$ \\
d2009 & $-3,5(-1,31)$ \\
Intercept & $2,36(0,26)$ \\
& \\
Number of obs. & 159 \\
$\mathrm{R}^{2}$ & 0.2047 \\
Adj R & \\
P-value & 0.0005 \\
\hline
\end{tabular}

The t-statistics are in parentheses; * - Significance at 15\%;

$* *$ - Significance at 10\%; *** - Significance at 5\%

$\uparrow$ - the model estimated by GLS, no endogeneity identified with Hausman test

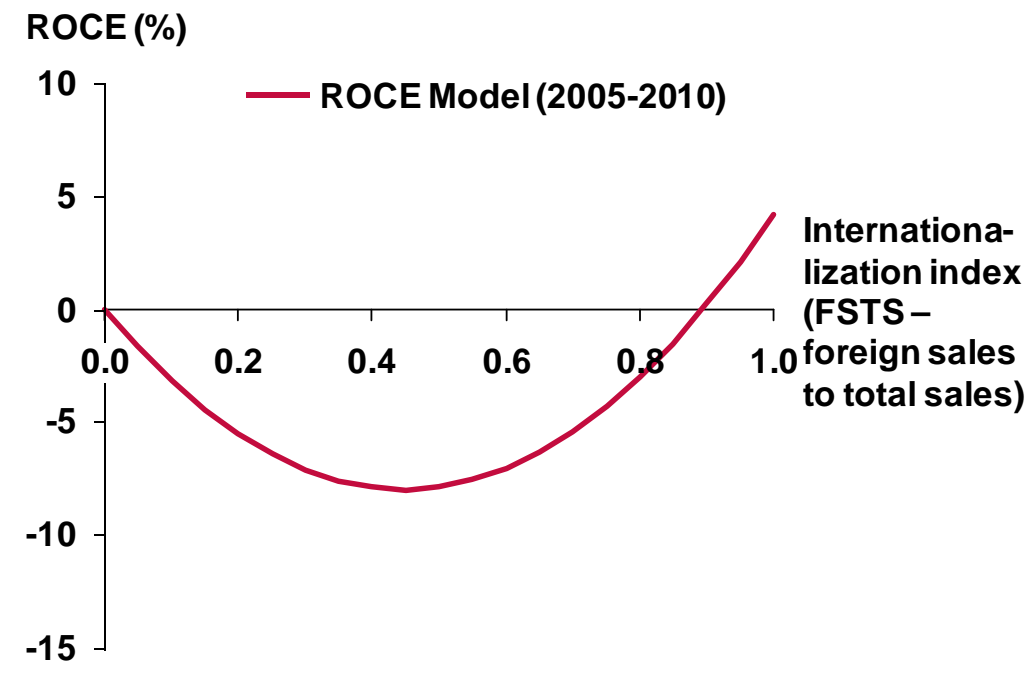

Figure 1. Internationalization-ROCE relationship: U-shaped form

\section{Conclusions and policy implications}

This paper contributes to the internationalization-performance literature by analyzing an effect of internationalization on current operational efficiency of large Russian companies measured by return on capital employed. The methodology of empirical estimation of internationalization efficiency has been developed and implemented.

It has been shown that internationalization-performance relationship follows a U-shape curve (the finding is consistent with the results of Contractor et al. (2007) derived for another emerging market - India). At the initial stage of international diversification corporate performance declines while at further stages of diversification it grows up.

As an implication of the present research for corporate decision makers it may be stated that 
at the initial level of international diversification the internationalization decisions should be made with a high degree of caution. The prestige and other irrational motives which may lead to the value destruction should be pruned. During the analysis of internationalization efficiency not only operational, but also financial effects should be counted. Companies should also be ready for a probable initial decline in operating performance motivated by an excess of internationalization costs over corresponding benefits.

\section{References}

1. Plotnikov I.V. (2010), Main directions of Russian outbound FDI, Federal educational portal ESM, Economic sciences. 64 (2010). № 3. pp. 293-296

2. Shcherbakov D.Y. (2011), Influence of corporate international diversification on its efficiency: does there exist an optimal level of corporate internationalization? // EJournal of Corporate Finance, 17 (2011), pp. 94-102

3. Bobillo A. M., Lopez-Iturriaga F., Tejerina-Gaite F. (2010), Firm performance and international diversification: The internal and external competitive advantages, International Business Review, 19 (2010) 607-618.

4. Capar N. and Kotabe M. (2003), The relationship between international diversification and performance in service firms, Journal of International Business Studies, 34 (2003), 345355.

5. Chang S., Wang C. (2007), The effect of product diversification strategies on the relationship between international diversification and firm performance, Journal of World Business, 42 (2007) 61-79.

6. Contractor F.J., Kumar V., Kundu S.K. (2007), Nature of the relationship between international expansion and performance: The case of emerging market firms, Journal of World Business, 42 (2007) 401-417.

7. Cuervo-Cazurra A. (2007), Sequence of value-added activities in the multinationalization of developing country firms, Journal of International Management, 13 (2007) 258-277.

8. Gugler K., Mueller D. C., Yurtoglu B. B., Zulehner C. (2003), The effects of mergers: an international comparison, International Journal of Industrial Organization, 21 (2003) 625653.

9. Hitt M., Hoskisson R., Kim H. (1997), International Diversification: Effects on Innovation and Firm Performance in Product-Diversified Firms, The Academy of Management Journal, 40(4) (1997) 767-798.

10. Hitt M. A., Tihanyi L., Miller T., Connelly B. (2006), International Diversification: Antecedents, Outcomes, and Moderators, Journal of Management, 32 (6) (2006) 831-867.

11. Lu J. W., Beamish P. W. (2004), International Diversification and Firm Performance: The SCurve Hypothesis, The Academy of Management Journal, 47(4) (2004) 598-609.

12. Moeller S. and Schlingemann F. (2004), Are cross-border acquisitions different from domestic acquisitions? Evidence on stock and operating performance for U.S. acquirers, Journal of Banking and Finance, (2004).

13. Qian G., Li J. (2002), Multinationality, global market diversification and profitability among the largest US firms, Journal of Business Research, 55 (2002) 325-335.

14. Rugman A. M., Oh C. H. (2010), Does the regional nature of multinationals affect the multinationality and performance relationship? International Business Review, 19 (2010) 479-488.

15. Seth Anju, Song Kean P., Pettit Richardson, (2000), Synergy, Managerialism or Hubris? An Empirical Examination of Motives for Foreign Acquisitions of U.S. Firms, Journal of International Business Studies, Vol. 31, No. 3 (3rd Qtr., 2000), pp. 387-405

16. Tan Hui, Ai Qi (2010), China's outward mergers and acquisitions in the 21st century: motivaitions, progress and the role of the Chinese government, Advances in Mergers and Acquisitions (Emerald Group Publishing Limited), Vol. 9, 25-50 
17. Verbeke A., Brugman P. (2009), Triple-testing the quality of multinationality-performance research: An internalization theory perspective, International Business Review, 18 (2009) $265-275$.

18. Wiersema M.F., Bowen H.P. (2008), Corporate diversification: the impact of foreign competition, industry globalization, and product diversification, Strategic Management Journal, 29(2) (2008) 115-227. 